\title{
Natural and Conventional Cosmetics-Mercury Exposure Assessment
}

\author{
Aleksandra Podgórska ${ }^{\dagger}$, Anna Puścion-Jakubik*,+(i), Anita Grodzka, Sylwia K. Naliwajko (1), \\ Renata Markiewicz-Żukowska (1) and Katarzyna Socha (1)
}

check for

updates

Citation: Podgórska, A.;

Puścion-Jakubik, A.; Grodzka, A.

Naliwajko, S.K.

Markiewicz-Żukowska, R.; Socha, K.

Natural and Conventional

Cosmetics-Mercury Exposure

Assessment. Molecules 2021, 26, 4088.

https://doi.org/10.3390/

molecules 26134088

Academic Editors: Juraj Majtan,

Marcela Bucekova and Milos Jesenak

Received: 11 May 2021

Accepted: 29 June 2021

Published: 5 July 2021

Publisher's Note: MDPI stays neutra with regard to jurisdictional claims in published maps and institutional affiliations.

Copyright: (c) 2021 by the authors. Licensee MDPI, Basel, Switzerland This article is an open access article distributed under the terms and conditions of the Creative Commons Attribution (CC BY) license (https:// creativecommons.org/licenses/by/ $4.0 /)$.
Department of Bromatology, Faculty of Pharmacy with the Division of Laboratory Medicine, Medical University of Białystok, Mickiewicza 2D Street, 15-222 Białystok, Poland; apodgorska1@student.umb.edu.pl (A.P.); aegrodzka@gmail.com (A.G.); sylwia.naliwajko@umb.edu.pl (S.K.N.); renmar@poczta.onet.pl (R.M.-Ż.); katarzyna.socha@umb.edu.pl (K.S.)

* Correspondence: anna.puscion-jakubik@umb.edu.pl; Tel.: +48-8574-854-69

+ These authors contributed equally to this work.

\begin{abstract}
Mercury $(\mathrm{Hg})$ can enter the human body through the respiratory tract and digestive system, but also through the skin. Sources of $\mathrm{Hg}$ in the environment can be natural processes, but also human activities, including agriculture, chemical, and pharmaceutical industries. $\mathrm{Hg}$ can also enter the body through food, but also with cosmetics that are used for a long time. Therefore, the aim of this study was to evaluate the $\mathrm{Hg}$ content in 268 randomly selected cosmetics: Natural and conventional, for face and body. $\mathrm{Hg}$ content was determined using an atomic absorption spectrometer (AMA 254, Leco, Prague, Czech Republic). It was shown that the face preparations were characterized by a significantly higher $\mathrm{Hg}$ content than the body preparations. No differences in the content of the tested element were found between natural and conventional preparations. $\mathrm{Hg}$ could be detected in all samples with concentrations measured from 0.348 to $37.768 \mu \mathrm{g} / \mathrm{kg}$.
\end{abstract}

Keywords: mercury; natural cosmetics; conventional cosmetics; face; body

\section{Introduction}

Mercury $(\mathrm{Hg})$ has been known and used by man for centuries, such as by Egyptians, Greeks, Romans, and Hindus since ancient times. Currently, despite the existence of restrictions on the use of $\mathrm{Hg}$, it is used in medicine, agriculture, and industry, including the cosmetics industry [1,2].

In nature, $\mathrm{Hg}$ occurs as metallic $\mathrm{Hg}$ and in the form of organic (e.g., methylmercury and ethylmercury) and inorganic compounds (e.g., Hg chlorides, sulfates, or nitrates) [1,2].

$\mathrm{Hg}$ enters the human body primarily through the respiratory system, alimentary tract, and also through the skin. Its absorption depends primarily on the form in which it occurs. Metallic $\mathrm{Hg}$ vapors are absorbed by the respiratory system in about $80 \%$. Organic and inorganic compounds are absorbed through the digestive tract, through the skin, and through the sweat and sebaceous glands of the skin [3].

The main source of $\mathrm{Hg}$ in the environment is from natural processes, e.g., volcanic eruptions or weathering of rocks, and human activity, which includes, among others, chemical and pharmaceutical industries, agriculture, and coal-fired heating and power plants [2-4]. Data on the monitoring of $\mathrm{Hg}$ content in soils and sediments have been published for many countries, as well as collected in collective summaries [5]. The increased content is due to local industrial pollution. For example, soils near the city of Qingzhen, China, had a maximum Hg content of 328.95 ppm. This was due to irrigation with river water contaminated with sewage [6]. Data from Poland indicates a content of 62-393 $\mathrm{mg} / \mathrm{kg}$ [7]. 
Important sources of exposure are also: a diet rich in marine and freshwater fish [8], amalgam fillings used in dentistry-especially dangerous in some subpopulations [9], and cosmetic products [10].

The permissible $\mathrm{Hg}$ contamination depends on the national regulations. $\mathrm{Hg}$ in cosmetic products can be an impurity but can also be intentionally added as preservatives: organic Hg compounds such as Thiomersal and phenylmercury salts (along with borate). The $\mathrm{Hg}$ contamination of cosmetics occurs during their production or as the result of improper cleaning of the raw materials used. The presence of $\mathrm{Hg}$ in cosmetic products, with two exceptions, Volpar and Thiomersal, is not permitted by law. Its trace amount in products can occur as contamination. Thiomersal and phenylmercuric salts may only be added to eye products at a maximum concentration of $0.007 \%$, expressed as $\mathrm{Hg}$. Cosmetics containing both of these compounds must be labeled with 'contains thiomersal' or 'contains phenylmercury compounds' [11-13]. According to US legislation, Hg must not be present in preparations, except in eye products—-this element must not exceed 65 parts per million (ppm) in the finished product. It can only be used when no other effective and safe preservative is available. Moreover, $\mathrm{Hg}$ is not allowed in any other cosmetic product except in trace amounts below 1 ppm, and only when its presence is unavoidable in accordance with good manufacturing practice (GMP) [14].

For example, in one publication regarding creams from Jamaica, the maximum content was 17,547 mg/kg [15], while in China, Japan, Sri Lanka, Taiwan, Thailand, and the United States, $6 \%$ of samples contained $\mathrm{Hg}$ above $1000 \mathrm{mg} / \mathrm{kg}$ [16]. The highest value characterized cream lightening and lifting purchased in-store in Thailand (45,622 $\pm 322 \mathrm{mg} / \mathrm{kg})$ [16]. Literature data indicate a high $\mathrm{Hg}$ content in cosmetics used to lighten the skin- $\mathrm{Hg}$ salts inhibit the formation of melanin, resulting in a lighter skin tone-sample result obtained in publications was $25.7 \mathrm{mg} / \mathrm{kg}$ [17]. A study published by Chen et al. (2020) showed that $\mathrm{HgCl}_{2}$ has the ability to directly inhibit tyrosinase, which explains the mechanism of action and toxicity of $\mathrm{Hg}$ [18].

In addition, the United States Environmental Protection Agency (US EPA) has published a guide to avoiding exposure to $\mathrm{Hg}$ from various sources, including creams, which may contain, for example, the term "anti-aging" or "skin lightening" [19].

RAPEX data is also very important. They are the result of non-food surveillance in the EU, where products with very high $\mathrm{Hg}$ content have been identified. Laboratories in national authorities carry out routine surveillance of over several hundred products that are on the EU market. Only the most dangerous products detected by random samples are reported under RAPEX, these results reflect exposure, but the scale of the problem appears to be much larger. For example, on 16 March 2021, a report was published on the lightening cream for the face, which contained $\mathrm{Hg}$ in an amount of $15,590 \mathrm{mg} / \mathrm{kg}$ [20]. The results published by Klaschka (2017) are also very disturbing. The author concluded that over 10 years, data on 724 cosmetic products were placed in the RAPEX system. The maximum recorded $\mathrm{Hg}$ content was as much as $42 \mathrm{~g} / \mathrm{kg}(42,000 \mathrm{mg} / \mathrm{kg})$ [21]. This result shows that controls by authorities in EU countries are very important.

The symptoms of $\mathrm{Hg}$ poisoning may appear in several organ systems and organs, including the skin. They include redness, rash, facial swelling, and excessive sweating. The changes also affect the hair, which becomes dry, brittle, thin, and dull, and its growth stops $[22,23]$.

According to the European packaging directive, the sum of lead, cadmium, $\mathrm{Hg}$, and chromium (VI) together may not exceed $100 \mathrm{mg} / \mathrm{kg}$ in packaging material [24].

The Hg content can be determined using various methods-they differ in the detection limit: atomic absorption apectrometry (limit of detection: $0.1 \mathrm{ng}$ ), atomic emission spectrometry $(0.005 \mathrm{ng})$, mass spectrometry $(0.005 \mathrm{ng})$, colorimetry $(100 \mathrm{ng})$, neutron activation analysis (0.01 ng), X-ray fluorescence spectrometry (25 ng), and electron-capture detection spectrometry $(0.5 \mathrm{ng})$ [25-30].

Despite the fact that companies conduct many campaigns regarding the safe use of cosmetics and comply with the requirements of GMP, $\mathrm{Hg}$ and its compounds still appear 
in cosmetic products, including those of the highest quality [31]. Therefore, the aim of this study was to assess the $\mathrm{Hg}$ content in random cosmetics both from natural and conventional origins. To the best of our knowledge, this is the first such comprehensive safety assessment of cosmetics used for face and body care.

\section{Results}

Hg Content in the Tested Cosmetics

Table 1 shows data on the median content of $\mathrm{Hg}$ in the tested cosmetics, taking into account the area of application and form. It was shown that the highest median $\mathrm{Hg}$ content was found in eye creams (3.850), quartile 1 (Q1): 0.383 , quartile 3 (Q3): $14.271 \mu \mathrm{g} / \mathrm{kg}$, serums (2.168, Q1: 0.359, Q3: $5.170 \mu \mathrm{g} / \mathrm{kg})$, and gels (2.005, Q1: 0.170, Q3: $7.964 \mu \mathrm{g} / \mathrm{kg})$.

Table 1. Hg concentration in the tested cosmetics.

\begin{tabular}{cccccc}
\hline \multicolumn{7}{c}{ Hg Concentration $(\mu \mathrm{g} / \mathbf{k g})$} \\
\hline Type of Cosmetics & $\boldsymbol{n}$ & Mean \pm SD & Min-Max & Med. & Q1-Q3 \\
\hline Body butter & 16 & $0.848 \pm 0.644$ & $0.050-2.127$ & 0.707 & $0.446-1.164$ \\
Body lotion & 34 & $0.683 \pm 0.419$ & $0.129-1.716$ & 0.612 & $0.314-0.854$ \\
Body milk & 22 & $0.521 \pm 0.404$ & $0.038-1.769$ & 0.428 & $0.245-0.834$ \\
Oil & 25 & $0.903 \pm 0.487$ & $0.204-1.974$ & 0.777 & $0.536-1.208$ \\
Peeling & 22 & $0.537 \pm 0.204$ & $0.218-0.942$ & 0.540 & $0.355-0.692$ \\
Serum & 15 & $0.538 \pm 0.260$ & $0.207-1.229$ & 0.486 & $0.360-0.733$ \\
& \multicolumn{7}{c}{ Face Cosmetics } & & \\
Cream & 46 & $2.759 \pm 2.914$ & $0.082-12.151$ & 1.640 & $0.214-4.860$ \\
Eye cream & 11 & $8.680 \pm 9.958$ & $0.202-28.561$ & 3.850 & $0.383-14.271$ \\
Foam & 4 & $0.428 \pm 0.392$ & $0.010-0.789$ & 0.456 & $0.094-0.761$ \\
Gel & 10 & $4.384 \pm 5.504$ & $0.021-14.260$ & 2.005 & $0.170-7.964$ \\
Hydrolate & 3 & $0.545 \pm 0.081$ & $0.482-0.636$ & 0.518 & $0.482-0.636$ \\
Mask & 17 & $1.114 \pm 1.601$ & $0.053-6.624$ & 0.525 & $0.177-1.439$ \\
Micellar liquid & 9 & $0.857 \pm 0.800$ & $0.003-2.334$ & 0.559 & $0.294-1.111$ \\
Serum & 16 & $5.055 \pm 9.235$ & $0.110-37.768$ & 2.168 & $0.359-5.170$ \\
SPF cream & 13 & $1.708 \pm 2.351$ & $0.010-8.330$ & 0.970 & $0.229-2.309$ \\
Tonic & 5 & $1.224 \pm 1.609$ & $0.036-3.813$ & 0.348 & $0.145-1.636$ \\
Total & 268 & $1.852 \pm 3.905$ & $0.003-37.768$ & 0.644 & $0.315-1.180$
\end{tabular}

Max: maximum; Med.: median; Min: minimum; $n$ : number of samples; Q1: quartile 1; Q3: quartile 3; SD: standard deviation.

It was shown that the face care products (median: $1.079 \mu \mathrm{g} / \mathrm{kg}, \mathrm{Q} 1: 0.229 \mu \mathrm{g} / \mathrm{kg}, \mathrm{Q} 3$ : $3.850 \mu \mathrm{g} / \mathrm{kg}$ ) were characterized by a significantly higher $\mathrm{Hg}$ content compared to the body care products (median: $0.591 \mu \mathrm{g} / \mathrm{kg}, \mathrm{Q} 1: 0.355 \mu \mathrm{g} / \mathrm{kg}, \mathrm{Q} 3: 0.479 \mu \mathrm{g} / \mathrm{kg}$ ) (Figure 1).

$\mathrm{Hg}$ content in natural cosmetics $(0.672 \mu \mathrm{g} / \mathrm{kg}, \mathrm{Q} 1: 0.357 \mu \mathrm{g} / \mathrm{kg}, \mathrm{Q} 3: 1.150 \mu \mathrm{g} / \mathrm{kg})$ and conventional cosmetics $(0.608 \mu \mathrm{g} / \mathrm{kg}, \mathrm{Q} 1: 0.306 \mu \mathrm{g} / \mathrm{kg}, \mathrm{Q} 3: 1.688 \mu \mathrm{g} / \mathrm{kg})$ did not differ statistically (Figure 2).

Institutions such as the Food and Drug Administration in the United States of America [14] allow the maximum $\mathrm{Hg}$ content in cosmetics to be $1 \mathrm{ppm}$ (i.e., $1000 \mu \mathrm{g} / \mathrm{kg}$ ) and only if its presence is unavoidable under GMP. Moreover, $\mathrm{Hg}$ compounds are only approved as preservatives in eye care products when there is no better and safer preservative. The concentration must not exceed $65 \mathrm{mg} / \mathrm{kg}$ in the finished product. This indicates that the toxic element $\mathrm{Hg}$ was detected in all tested cosmetic preparations, i.e., the cosmetics available for sale were in accordance with European or American law. 


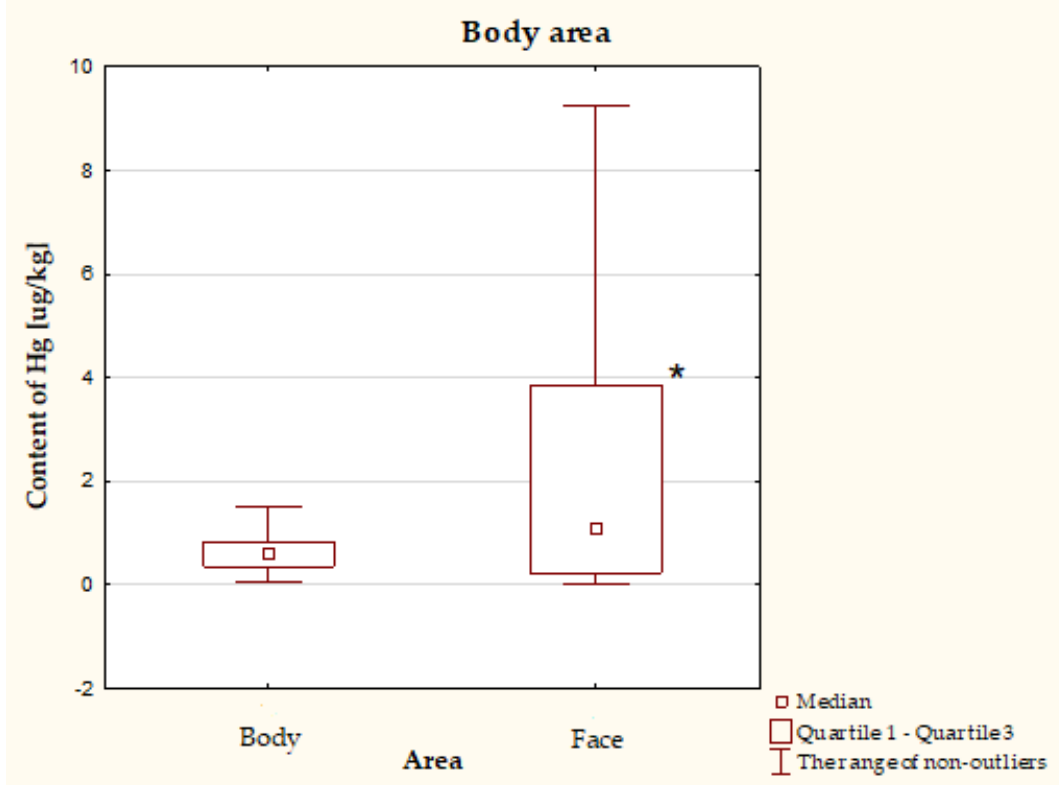

Figure 1. Hg concentration in body $(n=134)$ and face $(n=134)$ cosmetics. ${ }^{*} p<0.05$.

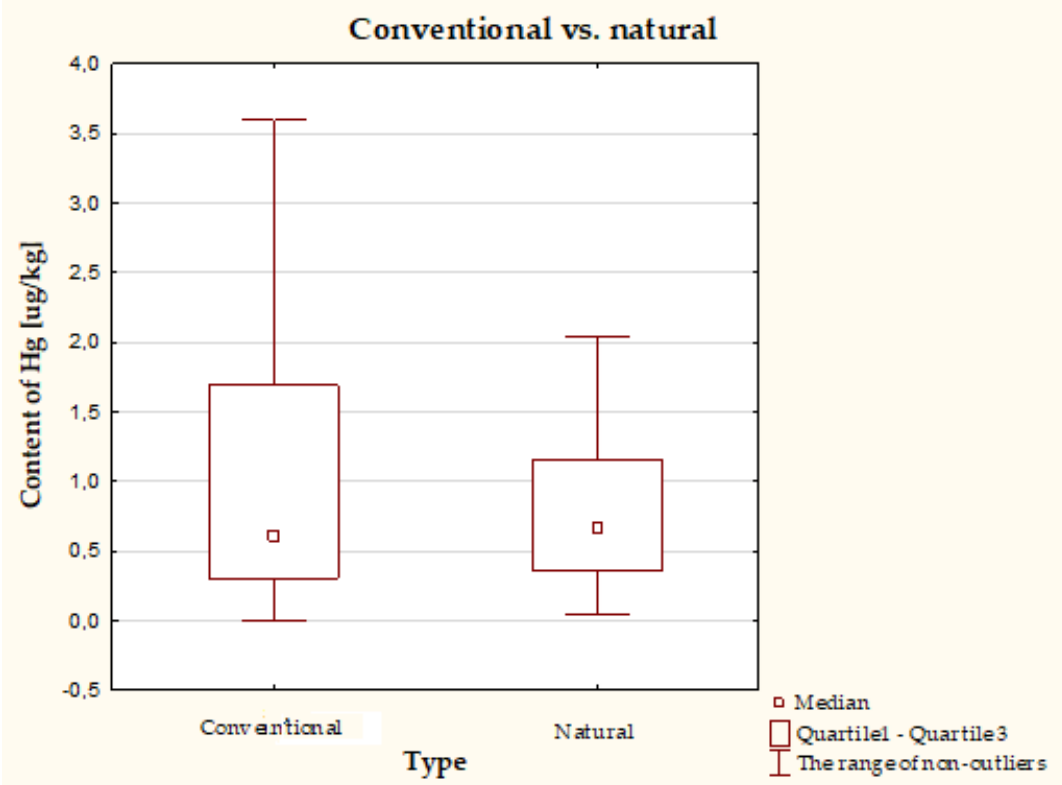

Figure 2. Concentration of $\mathrm{Hg}$ in conventional $(n=181)$ and natural $(n=87)$ cosmetics.

In addition, we found that the country of origin of a cosmetic has a significant impact on $\mathrm{Hg}$ content (Figure 3). 


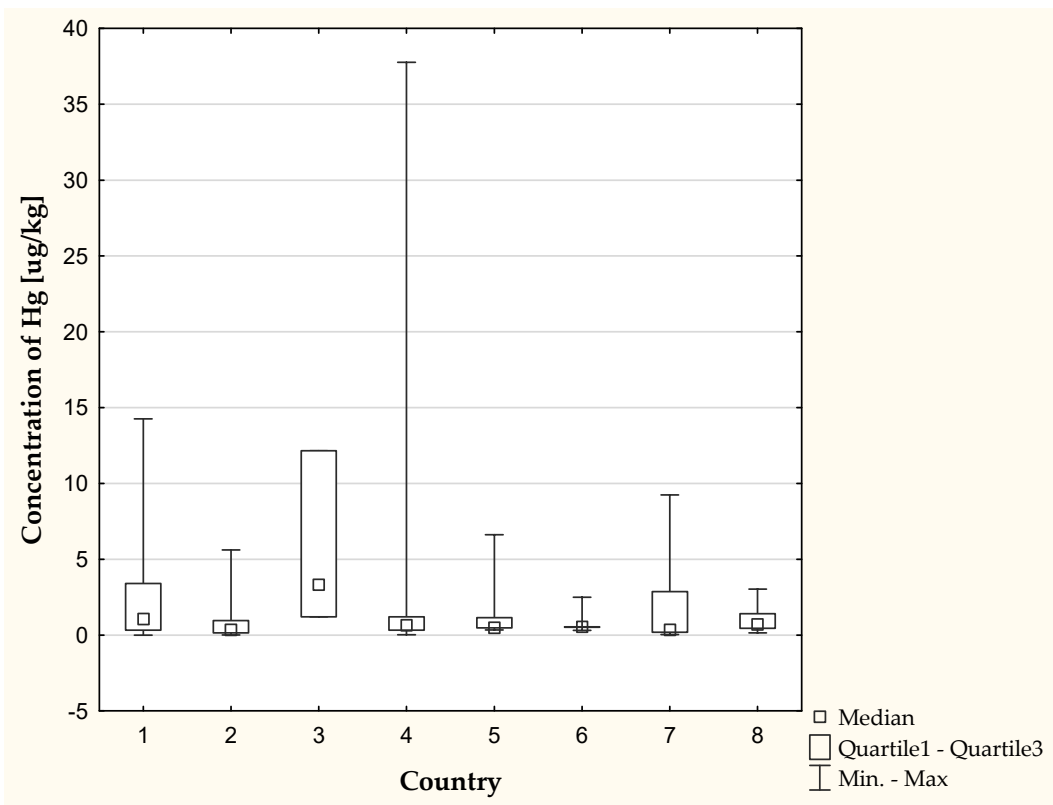

Figure 3. Concentration of $\mathrm{Hg}$ depending on the country of origin of the cosmetic $(p<0.05) .1$ : France; 2: Germany; 3: Korea; 4: Poland; 5: Russia; 6: UK; 7: USA; 8: Other.

As part of this study, health risk models, including carcinogenic and non-carcinogenic risks, were calculated based on data from the US EPA. The threshold values indicated by this institution were referred to [19]. Chronic exposure to $\mathrm{Hg}$ was assessed by calculating chronic daily intake (CDI) and hazard quotient (HQ) - indicating a non-carcinogenic risk [32].

It has been calculated that the CDI for body cosmetics is $8.72 \times 10^{-12}$, and for face cosmetics: $9.56 \times 10^{-15}$. The HQ was: $6.69 \times 10^{-9}$ and $7.36 \times 10^{-12}$, for body and face preparations, respectively.

\section{Discussion}

There are many sources of $\mathrm{Hg}$ exposure. The literature emphasizes various ways of human exposure to $\mathrm{Hg}$, e.g., the routes of entry may include the gastrointestinal tract (consumption of large amounts of freshwater and marine food and contaminated dietary supplements), the respiratory tract (as a result of human industrial activities and natural processes), but also the skin (e.g., from the use of Hg-contaminated preparations) [2]. Maximum threshold values written down in various legal instruments are only effective as long as competent authorities control their observation by appropriate surveillance programs and take subsequent action. The rapid alert system RAPEX [20] lists the most serious violations of provisions in non-food consumer products in the European Union, among them also many $\mathrm{Hg}$ containing personal care products [21].

Literature reports on the $\mathrm{Hg}$ content in cosmetics mainly include studies on the content of this toxic element in skin lightening creams. Data published in RAPEX show an alarming $\mathrm{Hg}$ content in skin lightening preparations: incl. 15,590 mg/ $\mathrm{kg}$ [20], $8061 \mathrm{mg} / \mathrm{kg}$ [33] and $7502 \mathrm{mg} / \mathrm{kg}$ [34]. This indicates the need to assess the quality of other cosmetics and assess the safety of their use.

Our research found that the $\mathrm{Hg}$ content depends on the country of origin of the cosmetic. Studies conducted on face creams $(n=6)$, commercially available in Bangladesh [35], showed that the highest $\mathrm{Hg}$ content was $481 \pm 9 \mu \mathrm{g} / \mathrm{kg}$, which was a value almost 13 times higher than the highest results obtained in our research (in serum, $37.768 \mu \mathrm{g} / \mathrm{kg}$ ). Studies on cosmetics from France, Italy, Switzerland, and the USA $(n=11)$ showed the content of $\mathrm{Hg}$ below limits of quantification $(0.16 \mathrm{ng} / \mathrm{g})$ [35]. The study by Peregrino et al. (2011) [36] showed the highest mean Hg content in skin-lightening creams at the level of 
$875 \pm 115 \mathrm{mg} / \mathrm{kg}$. The highest Hg content among skin whiteners cream in Cambodia was $12,590 \mu \mathrm{g} / \mathrm{g}$ (country of origin: China) [37].

In our study, we examined both conventional and natural cosmetics. In recent years, there has been an intense increase in consumer interest in natural cosmetics. The reason is the willingness to take care of health, belief in good recipes, or care for the environment and sustainable development.

The legislation lacks an unambiguous definition of a natural cosmetic, which is why such preparations should meet the standards set by certification institutions. These institutions, such as NATRUE or COSMOS (Cosmetics Organic and Natural Standard), take into account the following issues: use of appropriate quality raw materials and production methods, minimalistic use of substances, and packaging that can be recycled [38].

It should be emphasized that there are no publications comparing the quality of natural and conventional cosmetics, which is why we took up this issue. Interestingly, we showed that although Q3 was higher for conventional cosmetics, the median was higher for natural cosmetics, but this was not statistically significant.

The need to assess the safety of using natural cosmetics is indicated by their prevalence. Kaźmierczak and Wcisło-Dziadecka (2018) [39] conducted a questionnaire on women's opinions on the use of cosmetics of natural origin. Women from Poland $(n=114)$, aged 17 to 68 , were included in the study. The respondents indicated that they use this type of preparation for face care $(96.5 \%)$, beautifying $(94.8 \%)$, body $(87.9 \%)$, and hair care $(83.6 \%)$. Only half of the women $(49.1 \%)$ correctly indicated substances that should not be present in cosmetics labeled as natural. Interestingly, the key advantage of using natural cosmetics was the complete reduction or a reduction in the occurrence of allergic reactions [39]. However, literature data indicate that many natural products, including fragrances, are allergens [40]. Our research has shown that all tested preparations, both conventional and natural, meet the requirements for limit values for impurities; the natural preparations were characterized by a similar median $\mathrm{Hg}$ content. It should also be emphasized that the face care products were characterized by a significantly higher Hg content, and this type of skin care product is more often chosen by respondents.

The study conducted by Fisher et al. (2017) [41] were aimed at assessing the $\mathrm{Hg}$ content in plant raw materials, which are used in cosmetology. The following subjects were evaluated: cottonwood (Solidago virgaurea L.), horsetail (Equisetum arvense L.), nettle (Urtica dioica L.), St. John's wort (Hypericum perforatum L.), wormwood (Artemisia absinthium L.), and yarrow (Achillea millefolium L.). The authors showed that this content was in the range of $5-28 \mu \mathrm{g} / \mathrm{kg}$. These values are similar to those shown in cosmetics.

Contamination with the element usually occurs as a result of improper purification of natural raw materials, which are components of cosmetics, and during the production process of cosmetic products. Despite the observance of the principles of GMP, under which numerous production controls are carried out, as well as campaigns for the safe use of cosmetic products, $\mathrm{Hg}$ still appears in even high-quality cosmetics. While a single skin contact with a cosmetic containing $\mathrm{Hg}$ compounds is usually not associated with more serious side effects, long-term use of these products may lead to their accumulation, causing various health problems [31,35].

The relationship between the presence of Thiomersal and a pseudoallergic skin reaction was investigated by Peng et al. (2019) [42]. The study showed that MrgprB2/MRGPRX2 had an effect on Thimerosal-induced mast cell degranulation as well as the pseudoallergic response in mice-thus, it may play an important role in contact dermatitis in humans.

It should be emphasized that there is an aggregate exposure to $\mathrm{Hg}$ through various other products, not only cosmetic preparations. Other sources of exposure include food, packaging materials, clothing, electronics, etc.

Chronic exposure to $\mathrm{Hg}$ resulting from the use of cosmetics was assessed by Alam et al. (2019) [32]. The above study was carried out on only six creams frequently used by Bangladeshi people. The authors obtained a result of $\mathrm{HQ}$ higher than in our publication $\left(3.49 \times 10^{-9}\right)$. The highest value of the HQ, calculated for a single sample, was $8.67 \times 10^{-7}$, 
which was a value several times higher than that obtained in this study. An HQ value of less than 1 indicates that there is little risk of exposure to $\mathrm{Hg}$, both in the Bangladeshi population and in the Polish population. Some of the cosmetics we tested came from well-known, large cosmetic companies; hence, the estimate concerns a much larger population.

\section{Materials and Methods}

\subsection{Materials}

The research material consisted of 268 cosmetics, available in stationary and online sales and in pharmacies and cosmetics shops, from Polish and foreign companies. The Hg content of 134 body care preparations and 134 face preparations was assessed.

The products came from different countries: Canada $(n=1)$, China $(n=1)$, Czech Republic $(n=2)$, France $(n=47)$, Germany $(n=15)$, Greece $(n=1)$, Korea $(n=3)$, Norway $(n=1)$, Poland $(n=160)$, Russia $(n=5)$, Spain $(n=2)$, Sweden $(n=2)$, Switzerland $(n=1)$, United Kingdom $(n=5)$, and the USA $(n=22)$.

Among the body preparations the following were tested: body butters $(n=16)$, body lotions $(n=34)$, body milks $(n=22)$, oils $(n=25)$, peels $(n=22)$, and serums $(n=15)$.

Face care products included: creams $(n=46)$, eye creams $(n=11)$, foams $(n=4)$, gels $(n=10)$, hydrolates $(n=3)$, masks $(n=17)$, micellar fluids $(n=9)$, serums $(n=16)$, creams with SPF $(n=13)$, and tonics $(n=5)$.

Among the cosmetics included in the study, 181 were so-called 'conventional' preparations, and 87 , 'natural'.

We selected as many types of cosmetics for the study to best assess the risk of exposure to $\mathrm{Hg}$. All samples did not contain $\mathrm{Hg}$ components, as declared by the manufacturers.

\subsection{Methods}

$\mathrm{Hg}$ content in face and body care cosmetics was determined using an atomic absorption spectrometer (AMA 254, Leco, Prague, Czech Republic). With this spectrometer, it was possible to determine the total $\mathrm{Hg}$ content in liquid and solid samples, regardless of the form of occurrence. It is based on the amalgamation technique. The analyzer relies on the release of $\mathrm{Hg}$ from its organic and inorganic compounds, going into its atomic form. The measurement is performed directly; this method does not require prior mineralization of the sample, which is due to the easy formation of the $\mathrm{Hg}$ atomic cloud-the pyrolytic mineralization process takes place inside the apparatus. The measurement of the $\mathrm{Hg}$ content consists of three steps as described below [43]. Each sample was measured in triplicate, and the results are presented as the mean.

The first step involved drying and then burning the sample (weighing $0.02 \mathrm{~g}$ ) in a stream of oxygen (duration: $75 \mathrm{~s}$ ) [43].

The second stage involved passing the released $\mathrm{Hg}$ vapors through a catalytic column and then catching them by the amalgamator (150 s) [43].

The third step was to release $\mathrm{Hg}$ from the amalgamator and measure its content in measuring cuvettes at a wavelength of $254 \mathrm{~nm}$ (45 s) [43].

In order to determine the $\mathrm{Hg}$ concentration in the tested cosmetics, a standard curve was made on the basis of a standard $\mathrm{Hg}$ solution for atomic absorption spectrometry at a concentration of $1 \mathrm{~g} / \mathrm{L}$ (Merck, Darmstadt Germany). The curve has five points from 0 to $100 \mu \mathrm{g} / \mathrm{kg}$.

A method accuracy check was performed each day before starting the analysis and every 10 samples. The method of adding an internal standard of known concentration was used.

The limit of quantification is $0.003 \mathrm{ng} \mathrm{Hg}$. The relative standard deviation was $<1.5 \%$. 


\subsection{Evaluation of Chronic Exposure to $\mathrm{Hg}$}

The CDIdermal (chronic daily intake dermal) was calculated using the following equation [32]:

$$
\text { CDIdermal }=\frac{\mathrm{CS} \times \mathrm{SA} \times \mathrm{AF} \times \mathrm{ABS} \times \mathrm{EF} \times \mathrm{ED} \times \mathrm{CF}}{\mathrm{BW} \times \mathrm{AT}}
$$

CS: exposure-point concentration (mg/ $\mathrm{kg}$ ) (for body: 0.677, for face: 3.026);

SA: exposed skin area $\left(\mathrm{cm}^{2}\right)$ (for body: $30,000 \mathrm{~cm}^{2}$, for face: $3600 \mathrm{~cm}^{2}$ );

AF: adherence factor $\left(\mathrm{mg} / \mathrm{cm}^{2}\right)(0.07)$;

ABS: dermal absorption fraction (no units) (0.001);

EF: exposure frequency (days/year) (350);

ED: exposure duration (year) (30);

CF: units conversion factor $(\mathrm{kg} / \mathrm{mg})\left(10^{-6}\right)$;

BW: body weight $(\mathrm{kg})(70)$;

AT: mean time for non-carcinogens (days) $(25,550)$.

The HQ (hazard quotient) was calculated using the following formula [30]:

$$
\mathrm{HQ}=\frac{\text { CDIdermal }}{\text { RfDdermal }}
$$

Reference dose (RfDermal) for Hg: $0.0013 \mathrm{mg} / \mathrm{kg} /$ day [30].

\subsection{Statistical Analysis}

Statistical analysis was performed using the Statistica 13.3 program (Statsoft, Tibco, Palo-Alto, CA, USA).

The normality of the data distribution was examined by means of the Shapiro-Wilk's test, Kolmogorov-Smirnov test, and Lilliefors test. The Mann-Whitney U-test was used to show the differences in $\mathrm{Hg}$ content between the two groups, and the Kruskal-Wallis ANOVA test between several groups. The differences were assumed to be statistically significant at $p<0.05$.

\section{Conclusions}

All cosmetic products tested, both conventional and natural, were found to contain $\mathrm{Hg}$ above the detection limit. Due to the frequency of application, applying multiple layers, as well as the large body surface area they are applied to, the $\mathrm{Hg}$ content of these products should be monitored. Our data lead us to the important final conclusion: on the one hand, it is believed that values below the acceptable standards mean that cosmetics are safe. On the other hand, $\mathrm{Hg}$ is a toxic element, so exposure to even a small amount is a hazard to human health. There is no theoretically safe level for this highly toxic element-any concentration above zero is unsafe.

Author Contributions: Conceptualization, A.P.-J., R.M.-Ż., and K.S.; Data curation, A.P.-J.; Formal analysis, A.P.-J., S.K.N., R.M.-Ż., and K.S.; Funding acquisition, K.S.; Investigation, A.P., A.P.-J., and A.G.; Methodology, A.P.-J., S.K.N., R.M.-Ż., and K.S.; Project administration, A.P.-J., R.M.-Ż., and K.S.; Resources, A.P.-J., S.K.N., R.M.-Ż., and K.S.; Software, A.P., A.P.-J., and A.G.; Supervision, K.S.; Validation, A.P.-J.; Writing-original draft, A.P. and A.P.-J.; Writing—review and editing, S.K.N., R.M.-Ż., and K.S. All authors have read and agreed to the published version of the manuscript.

Funding: This research received no external funding.

Institutional Review Board Statement: Not applicable.

Informed Consent Statement: Not applicable.

Data Availability Statement: Detailed data is available from the authors. 
Conflicts of Interest: The authors declare no conflict of interest. The funders had no role in the design of the study; in the collection, analyses, or interpretation of data; in the writing of the manuscript, or in the decision to publish the results.

Sample Availability: Not applicable.

\section{References}

1. Clarkson, T.W.; Magos, L. The Toxicology of Mercury and Its Chemical Compounds. Crit. Rev. Toxicol. 2006, 36, 609-662. [CrossRef]

2. Seńczuk, W. Toksykologia Wspótczesna; PZWL: Warsaw, Poland, 2020; pp. 427-435. (In Polish)

3. Bernhoft, R.A. Mercury Toxicity and Treatment: A Review of the Literature. J. Environ. Public Health 2011, 2012, 1-10. [CrossRef]

4. Pacyna, E.G.; Pacyna, J.M.; Fudała, J.; Strzelecka-Jastrząb, E.; Hlawiczka, S.; Panasiuk, D.; Nitter, S.; Pregger, T.; Pfeiffer, H.; Friedrich, R. Current and future emissions of selected heavy metals to the atmosphere from anthropogenic sources in Europe. Atmos. Environ. 2007, 41, 8557-8566. [CrossRef]

5. Beckers, F.; Rinklebe, J. Cycling of mercury in the environment: Sources, fate, and human health implications: A review. Crit. Rev. Environ. Sci. Technol. 2017, 47, 693-794. [CrossRef]

6. Matsuyama, A.; Liya, Q.; Yasutake, A.; Yamaguchi, M.; Aramaki, R.; Xiaojie, L.; Pin, J.; Li, L.; Mei, L.; Yumin, A.; et al. Distribution of Methylmercury in an Area Polluted by Mercury Containing Wastewater from an Organic Chemical Factory in China. Bull. Environ. Contam. Toxicol. 2004, 73, 846-852. [CrossRef] [PubMed]

7. Boszke, L.; Kowalski, A.; Astel, A.; Barański, A.; Gworek, B.; Siepak, J. Mercury mobility and bioavailability in soil from contaminated area. Environ. Earth Sci. 2007, 55, 1075-1087. [CrossRef]

8. Li, W.; Wang, W.-X. In vivo oral bioavailability of fish mercury and comparison with in vitro bioaccessibility. Sci. Total. Environ. 2019, 683, 648-658. [CrossRef] [PubMed]

9. Homme, K.G.; Kern, J.K.; Haley, B.E.; Geier, D.A.; King, P.G.; Sykes, L.K.; Geier, M.R. New science challenges old notion that mercury dental amalgam is safe. BioMetals 2014, 27, 19-24. [CrossRef]

10. Borowska, S.; Brzóska, M.M. Metals in cosmetics: Implications for human health. J. Appl. Toxicol. 2015, 35, 551-572. [CrossRef] [PubMed]

11. Regulation (EC) No $1223 / 2009$ of the European Parliament and of the Council of 30 November 2009 on Cosmetic Products. Available online: https:/ / www.legislation.gov.uk/eur/2009/1223/contents (accessed on 1 May 2021).

12. Bocca, B.; Pino, A.; Alimonti, A.; Forte, G. Toxic metals contained in cosmetics: A status report. Regul. Toxicol. Pharmacol. 2014, 68, 447-467. [CrossRef]

13. Copan, L.; Fowles, J.; Barreau, T.; McGee, N. Mercury Toxicity and Contamination of Households from the Use of Skin Creams Adulterated with Mercurous Chloride (Calomel). Int. J. Environ. Res. Public Health 2015, 12, 10943-10954. [CrossRef] [PubMed]

14. FDA's Testing of Cosmetics for Arsenic, Cadmium, Chromium, Cobalt, Lead, Mercury, and Nickel Content. Available online: https:/ / www.fda.gov/cosmetics/potential-contaminants-cosmetics/fdas-testing-cosmetics-arsenic-cadmium-chromiumcobalt-lead-mercury-and-nickel-content (accessed on 1 May 2021).

15. Ricketts, P.; Knight, C.; Gordon, A.; Boischio, A.; Voutchkov, M. Mercury Exposure Associated with Use of Skin Lightening Products in Jamaica. J. Health Pollut. 2020, 10, 200601. [CrossRef] [PubMed]

16. Hamann, C.; Boonchai, W.; Wen, L.; Sakanashi, E.N.; Chu, C.-Y.; Hamann, K.; Hamann, C.P.; Sinniah, K.; Hamann, D. Spectrometric analysis of mercury content in 549 skin-lightening products: Is mercury toxicity a hidden global health hazard? J. Am. Acad. Dermatol. 2014, 70, 281-287.e3. [CrossRef] [PubMed]

17. Naser, J.; Kirm, I. Mercury content in low cost skin lightening cream products. J. Environ. Sci. Eng. 2012, 54, 245-248. [PubMed]

18. Chen, J.; Ye, Y.; Ran, M.; Li, Q.; Ruan, Z.; Jin, N. Inhibition of Tyrosinase by Mercury Chloride: Spectroscopic and Docking Studies. Front. Pharmacol. 2020, 11, 81. [CrossRef] [PubMed]

19. United States Environmental Protection Agency. Available online: https://www.epa.gov/mercury (accessed on 20 June 2021).

20. European Commission, Safety Gate: The EU Rapid Alert System for Dangerous Non-Products. Available online: https:/ /ec. europa.eu/safety-gate-alerts/screen/webReport/alertDetail/10003132 (accessed on 20 June 2021).

21. Klaschka, U. Trust, but verify! Personal care products in the rapid alert system database RAPEX. Sustain. Chem. Pharm. 2017, 5, 30-41. [CrossRef]

22. Żukiewicz-Sobczak, W.A.; Adamczuk, P.; Wróblewska, P.; Zwoliński, J.; Chmielewska-Badora, J.; Krasowska, E.; Galińska, E.M.; Cholewa, G.; Piatek, J.; Koźlik, J. Allergy to selected cosmetic ingredients. Adv. Dermatol. Allergol. 2013, 30, 307-310. [CrossRef]

23. Cutler, A. Amalgam Illness: Diagnosis and Treatment; Andrew Hall Culter: Sammamish, WA, USA, 1999; pp. 25-39.

24. Minister Środowiska [The Minister of Environment]. Rozporządzenie Ministra Środowiska z dnia 21 stycznia 2015 r. w sprawie opakowań, do których nie stosuje się wymagań dotyczących zawartości ołowiu, kadmu, rtęci i chromu sześciowartościowego w opakowaniach, Dz.U. 2015 poz. 137; Dziennik Ustaw Rzeczypospolitej Polskiej: Warsaw, Poland, 2015 [in Polish, Regulation of the Minister of the Environment of 21 January 2015 on packaging to which the requirements regarding the content 467 of lead, cadmium, mercury and hexavalent chromium in packaging do not apply].

25. Urba, A.; Kvietkus, K.; Sakalys, J.; Xiao, Z.; Lindqvist, O. A new sensitive and portable mercury vapor analyzer Gardis-1A. Water Air Soil Pollut. 1995, 80, 1305-1309. [CrossRef] 
26. Dietz, C.; Madrid, Y.; Camara, C. Mercury speciation using the capillary cold trap coupled with microwave-induced plasma atomic emission spectroscopy. J. Anal. At. Spectrom. 2001, 16, 1397-1402. [CrossRef]

27. Ministry of the Environment. Minamata Disease Archives. Available online: http://nimd.env.go.jp/archives/english/index.html (accessed on 20 June 2021).

28. Jones, P.; Hardy, S. Development of a capillary electrophoretic method for the separation and determination of trace inorganic and organomercury species utilizing the formation of highly absorbing water soluble dithizone sulphonate complexes. J. Chromatogr. A 1997, 765, 345-352. [CrossRef]

29. Aretaki, I.; Koulouridakis, P.; Kallithrakas-Kontos, N. Total reflection X-ray fluorescence mercury analysis after immobilization on quartz surfaces. Anal. Chim. Acta 2006, 562, 252-257. [CrossRef]

30. Caricchia, A.; Minervini, G.; Soldati, P.; Chiavarini, S.; Ubaldi, C.; Morabito, R. GC-ECD Determination of Methylmercury in Sediment Samples Using a SPB-608 Capillary Column after Alkaline Digestion. Microchem. J. 1997, 55, 44-55. [CrossRef]

31. Moniczewski, A.; Starek, M.; Rutkowska, A. Toksykologiczne aspekty zanieczyszczeń metalicznych w kosmetykach. Med. Inter. Rev. 2016, 27, 81-90. (In Polish)

32. Alam, M.F.; Akhter, M.; Mazumder, B.; Ferdous, A.; Hossain, M.D.; Dafader, N.C.; Ahmed, F.T.; Kundu, S.K.; Taheri, T.; Ullah, A.K.M.A. Assessment of some heavy metals in selected cosmetics commonly used in Bangladesh and human health risk. J. Anal. Sci. Technol. 2019, 10, 2. [CrossRef]

33. European Commission. Safety Gate: The EU Rapid Alert System for Dangerous Non-Products. Available online: https: / / ec.europa.eu/safety-gate-alerts/screen/webReport/alertDetail/10003121 (accessed on 20 June 2021).

34. European Commission. Safety Gate: The EU Rapid Alert System for Dangerous Non-Products. Available online: https: / / ec.europa.eu/safety-gate-alerts/screen/webReport/alertDetail/10003131 (accessed on 20 June 2021).

35. Bocca, B.; Forte, G.; Petrucci, F.; Cristaudo, A. Levels of nickel and other potentially allergenic metals in Ni-tested commercial body creams. J. Pharm. Biomed. Anal. 2007, 44, 1197-1202. [CrossRef]

36. Peregrino, C.P.; Moreno, M.V.; Miranda, S.V.; Rubio, A.D.; Leal, L.O. Mercury Levels in Locally Manufactured Mexican SkinLightening Creams. Int. J. Environ. Res. Public Health 2011, 8, 2516-2523. [CrossRef]

37. Murphy, T.; Slotton, D.G.; Irvine, K.; Sukontason, K.; Goldman, C.R. Mercury Contamination of Skin Whiteners in Cambodia. Hum. Ecol. Risk Assess. Int. J. 2009, 15, 1286-1303. [CrossRef]

38. Barros, C.; Barros, R.B.G. Natural and organic cosmetics: Definition and concepts. J. Cosmetol. Trichol. 2020, 6. [CrossRef]

39. Kaźmierczak, A.; Wcisło-Dziadecka, D. Wpływ świadomości konsumentów na wybór kosmetyków naturalnych. Kosmetol. Estet. 2018, 5, 501-503. (In Polish)

40. Klaschka, U. Naturally toxic: Natural substances used in personal care products. Environ. Sci. Eur. 2015, 27, 1. [CrossRef]

41. Fischer, A.; Brodziak-Dopierała, B.; Loska, K.; Stojko, J. The Assessment of Toxic Metals in Plants Used in Cosmetics and Cosmetology. Int. J. Environ. Res. Public Health 2017, 14, 1280. [CrossRef] [PubMed]

42. Peng, B.; Che, D.; Hao, Y.; Zheng, Y.; Liu, R.; Qian, Y.; Cao, J.; Wang, J.; Zhang, Y.; He, L.; et al. Thimerosal induces skin pseudo-allergic reaction via Mas-related G-protein coupled receptor B2. J. Dermatol. Sci. 2019, 95, 99-106. [CrossRef] [PubMed]

43. Spectro-Lab. Laboratoria Przyszłości, Analizator Rtęci AMA 254. Available online: http://www.spectro-lab.pl/produkt/ analizator-rteci-ama-254/ (accessed on 20 June 2021). (In Polish) 